\title{
Effect of Rust (Uromyces Phaseoli Var. Vignae) Infection on Photosynthetic Efficiency, Growth and Yield Potentials of Cowpea (Vigna Unguiculata L. Walp) in an Open Field System

\author{
By S. M. A. Tagoe, T. A. Mensah \& A. T. Asare
} \\ University of Cape Coast
}

Abstract- Cowpea rust fungus affects photosynthetic rate and physiological performance of the host plant through the induction of structural changes in the host cell. The study assessed the effects of rust fungus on net photosynthetic efficiency and yield performance of cowpea genotypes under field conditions. The experiment was conducted in the minor cropping season following a randomized complete block design outlay with three replications. Chlorophyll fluorescence of healthy leaves and rust-infected leaves of each cowpea genotype was determined by a non-destructive method. Rust disease severities of the infected leaves were assessed based on a diagrammatic scale. The effect of rust on the net photosynthetic rate was quantified by the model Px / Po $=(1-x)^{\beta}$. Growth and yield traits of the cowpea genotypes and correlation between seed yield and photosynthetic efficiency were determined. The cowpea genotypes responded differently to rust infection as expressed in net photosynthetic rates, growth, and yield. The pathogen impaired photosynthetic efficiency of leaf tissue beyond the observed diseased leaf area. Seed yield was more closely related to the $\beta$ estimate than that observed for the relative net photosynthetic rate.

Keywords: cowpea; rust pathogen; disease severity; photosynthetic rate; growth; yield.

GJSFR-C Classification: FOR Code: 069999

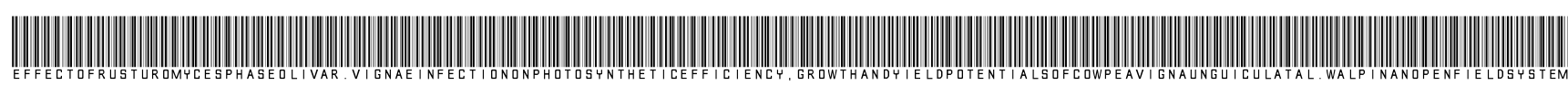

Strictly as per the compliance and regulations of:

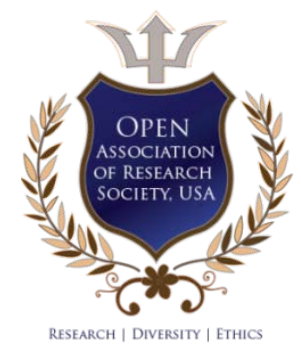

(c) 2020. S. M. A. Tagoe, T. A. Mensah \& A. T. Asare. This is a research/review paper, distributed under the terms of the Creative Commons Attribution-Noncommercial 3.0 Unported License http://creativecommons.org/licenses/by-nc/3.0/), permitting all non commercial use, distribution, and reproduction in any medium, provided the original work is properly cited. 


\title{
Effect of Rust (Uromyces Phaseoli Var. Vignae) Infection on Photosynthetic Efficiency, Growth and Yield Potentials of Cowpea (Vigna Unguiculata L. Walp) in an Open Field System
}

\author{
S. M. A. Tagoe $^{\alpha}$, T. A. Mensah $^{\sigma} \&$ A. T. Asare $^{\rho}$
}

\begin{abstract}
Cowpea rust fungus affects photosynthetic rate and physiological performance of the host plant through the induction of structural changes in the host cell. The study assessed the effects of rust fungus on net photosynthetic efficiency and yield performance of cowpea genotypes under field conditions. The experiment was conducted in the minor cropping season following a randomized complete block design outlay with three replications. Chlorophyll fluorescence of healthy leaves and rust-infected leaves of each cowpea genotype was determined by a non-destructive method. Rust disease severities of the infected leaves were assessed based on a diagrammatic scale. The effect of rust on the net photosynthetic rate was quantified by the model $\mathrm{Px} / \mathrm{Po}=(1-x)^{\beta}$. Growth and yield traits of the cowpea genotypes and correlation between seed yield and photosynthetic efficiency were determined. The cowpea genotypes responded differently to rust infection as expressed in net photosynthetic rates, growth, and yield. The pathogen impaired photosynthetic efficiency of leaf tissue beyond the observed diseased leaf area. Seed yield was more closely related to the $\beta$ estimate than that observed for the relative net photosynthetic rate. Further studies should evaluate the effects of rust-infection on whole-plant physiology of the cowpea genotypes to construct a model to successfully quantify the relationship between rust infection and seed yield of cowpeas. Keywords: cowpea; rust pathogen; disease severity; photosynthetic rate; growth; yield.
\end{abstract}

\section{INTRODUCTION}

C owpea (Vigna unguiculata L. Walp) is an important leguminous food crop and plays a critical role in sustenance of about 194 million people in Africa (Abate et al., 2012; Dugje et al., 2009). In Ghana, cowpea is both food security and a cash crop (Rusike et al., 2013). More than 95\% of the dry matter content of cowpea is obtained from photosynthesis (Bate and Canvin, 1971; Chapin III and Eviner, 2003; Ho, 1976). Cowpea is typically a C3 plant and therefore follows the $\mathrm{C} 3$ photosynthesis pathway (Kassman et al.,

Author a $\sigma \rho$ : Department of Molecular Biology and Biotechnology, University of Cape Coast, Cape Coast, Ghana.

e-mails: stagoe@ucc.edu.gh, theophilus.mensah2@stu.ucc.edu.gh, theoabonyi88@gmail.com, aasare@ucc.edu.gh
1991). Cowpea belongs to the crop stability group II of C3 plants and operates under warm conditions with a potential rate of photosynthesis $\left(40-50 \mathrm{mg} \mathrm{CO}_{2} \mathrm{dm}^{-2} \mathrm{~h}^{-2}\right)$ greater than group I C3 crops (20-30 mg CO $2 \mathrm{dm}^{-2} \mathrm{~h}^{-2}$ ) such as common bean, barley, wheat, and oat (Kassman et al., 1991). C3 photosynthesis is a multistep process and occurs in virtually all leaf mesophyll cells (Ehleringer and Cerling, 2002). The photosynthetic process is largely dependent on stomatal regulation and the amount of chlorophyll present (Brito et al., 2012; Evans, 2013). However, the concentration of chlorophyll may be influenced by responses to biotic and abiotic stresses (Hailemichael et al., 2016; Lobato et al., 2010; Sheikh et al., 2017). Variation in chlorophyll content of healthy and stressed plants provide valuable information about the physiological condition of the plant (Kamble et al., 2015; Sims and Gamon, 2002; Steele et al., 2008).

Cowpea rust fungus (Uromyces phaseoli var. vignae) is the most important biotic constraint to high yield and production of cowpea (Deshpand et al., 2010; Honnur et al., 2016; Uma et al., 2016). The fungus infects host leaves and is disseminated through the airborne urediniospores (Uma et al., 2016). The pathogen reduces foliar area and photosynthetic activity considerably in cowpea through destruction and reduction of most of the photosynthetic surface area, and interference with the photosynthetic activity of the healthy green parts of the host plant (Honnur et al., 2016; Newcombe, 2004; Singh, 2011). Toxins such as tentoxin and tabtoxin produced by rust fungus inhibit the activities of some enzymes involved directly or indirectly in photosynthesis in cowpea (Agrios, 2004). Cowpea rust fungus consumes photosynthetic products of host leaves and causes premature defoliation and mortality of young and mature plants, leading to reduced seed size and severe yield loss of 60-80\% (Deshpand et al., 2010; Leonard and Szabo, 2005; Uma et al., 2016; Voegele and Mendgen, 2003). The effects of rust disease on cowpea is more severe in the tropical and subtropical regions of the world, particularly Africa, due to the dry, warm, and high humid conditions that are 
conducive for rust disease development and spore dissemination (Kumar and Narain, 2005).

Despite these, knowledge about the photosynthetic metabolism of cowpea cultivars infected with cowpea rust fungus is limited. Determination of the amount of chlorophyll is often employed by scientists to assess photosynthetic performance in vegetative plants. Destructive techniques have been conventionally used to determine leaf chlorophyll content in crops (Brito et al., 2012). The chlorophyll content of various plant species have been determined using $80 \%$ acetone $\left(\mathrm{C}_{3} \mathrm{H}_{6} \mathrm{O}\right)$ and magnesite $\left(\mathrm{MgCO}_{3}\right)$ powder followed by spectrophotometric analysis (Kamble et al., 2015; Sheikh et al., 2017). Makeen et al. (2007) estimated chlorophyll content in Black gram (Vigna mungo L.) using methanol and dimethyl sulfoxide (DMSO). Diethyl ether (DEE) and dimethylformamide (DMF) are highly recognized as best solvents for chlorophyll extraction (Etemadian et al., 2017; Stiegler et al., 2005; Sumanta et al., 2014). However, these techniques are very laborious, expensive, time-consuming, and involve destructive sampling, various procedural steps, and a high volume of solvent which leads to dilute or poor yield of chlorophyll (Kamble et al., 2015; Makeen et al., 2007). Complete extraction of chlorophyll is difficult to achieve in etiolated plants due to the presence of a low concentration of chlorophyll (Makeen et al., 2007). Besides, the use of solvents such as methanol, DMF, and DMSO is not recommended for chlorophyll extraction as the solvents are toxic to humans and easily absorbed by the skin (de Abreu Costa et al., 2017; Kadam et al., 2018; Long et al., 2001).

Chlorophyll fluorescence meters have been extensively used in research and agricultural applications to determine chlorophyll content of leaves because they are non-destructive to leaf tissue, portable, quick, and easy to use. They also have high accuracy and do not require specially trained personnel (Cate and Perkins, 2003; Chapman and Barreto, 1997; Ling et al., 2011). The plant photosynthesis meter (mini PPM-300, EARS) was used to determine leaf photosynthesis in this work. The meter uses a light emitting diode to elicit and recognize the fluorescence of chlorophyll (EARS, 2009; Fernandez-Jaramillo et al., 2012). The mini PPM-300 instantaneously measures fluorescence yield, photosynthesis yield, photosyntheticcally active radiation and photosynthetic rate of plant leaves based on quantification of light intensity wavelengths between $300 \mathrm{~nm}$ and $800 \mathrm{~nm}$. The data generated is stored in the meter and can easily be assessed.

Although crop productivity is mainly determined by the efficiency of photosynthesis under a specific environmental condition and available resources, measurement of leaf photosynthesis does not necessarily predict improvement in crop growth and yield since the individual leaves used are not representative of the photosynthetic behavior of the entire crop canopy (Dutton et al., 1988; Elmore, 1980; Singh, 2011). A positive correlation between photosynthesis and productivity in crops, therefore, require a considerable sampling and assessment of various plant parts (Ambavaram et al., 2014; Jiang et al., 2017; Long et al., 2015; Silva et al., 2017). Components for determining cowpea growth and yields such as plant height, number of branches per plant, number of seeds per pod, pod length, and 100-seed weight have been adjudged as important selection traits for genetic improvement of the crop since they are moderate to highly heritable (Adigun et al., 2014; Nwofia et al., 2014).

Several studies have reported variability in cowpea growth and yield components, but the relationship of these parameters with photosynthetic performance in rust-infected leaves is limited (Afutu et al., 2016; Agyeman et al., 2014; Sharma et al., 2017; Shweta and Singh, 2018). The study showed the effect of cowpea rust infection on the efficiency of the net photosynthetic rate of cowpea genotypes based on the virtual lesion concept by Bastiaans (1991) and described the relationship between net photosynthetic efficiency and seed yield. The identification of promising cowpea genotypes with high yield potentials amidst rust infection is necessary to establish the appropriate agronomic manipulations for obtaining high yields in cowpea production, particularly in endemic rust areas in producing countries.

\section{il. Materials and Methods}

\section{a) Study area}

The study was conducted at the University of Cape Coast Teaching and Research Farm during the minor cropping season of 2017 because rust disease development in the area is generally higher in the minor season compared with the major season. The study area falls within the coastal savannah agro-ecological zone of Ghana and coordinated on latitude $05^{\circ} 08^{\prime} \mathrm{N}$ and longitude $01^{\circ} 18^{\prime} \mathrm{W}$. The area was characterized by a mean temperature of $28.5^{\circ} \mathrm{C}$ and rainfall of $545.50 \mathrm{~mm}$ during the study period.

\section{b) Sowing of cowpea seeds}

Twenty-four (24) cowpea genotypes comprising two local lines from the Savanna Agriculture Research Institute (SARI), six accessions from the International Institute of Tropical Agriculture (IITA), and 16 recombinant inbred lines (RILs) from the University of Cape Coast (UCC) were obtained from the Department of Molecular Biology and Biotechnology, UCC for the study (Table 1). The selected cowpea genotypes have different responses to rust infection (Mensah et al., 2019), maturity periods (55-75 days), and usage (grown for seeds and leaves). The genotypes have flower color of either violet, cream, violet-pink, or white. The seed coat color ranges from white, red, brown, cream, 
mottled red, rough brown to speckled white. The experimental plot was cleared, demarcated, and divided into blocks at $1 \mathrm{~m}$ intervals. The blocks were further divided into subplots of $3 \mathrm{~m} \times 3 \mathrm{~m}$ at $1 \mathrm{~m}$ interval between two subplots. The plot was sprayed with a $2 \%$ solution of Roundup weedicide (Monsanto Europe N.V.) after two weeks of weed emergence. One cowpea genotype was sowed in a subplot. The cowpea seeds were sowed at two seeds per hole at a spacing of $40 \mathrm{~cm}$ within rows and $60 \mathrm{~cm}$ between rows. The experiment was set up in a randomized complete block design outlay with three replications and was manually weeded at 3 and 6 weeks after seed germination.

Table 1: Cowpea genotypes used for evaluation of rust disease

\begin{tabular}{|c|c|c|c|c|c|c|c|}
\hline SI. No. & Genotype & Source & Response to rust & SI. No. & Genotype & Source & Response to rust \\
\hline 1 & UCC-11 & UCC & Moderately resistant & 13 & UCC-490 & UCC & Moderately resistant \\
\hline 2 & UCC-24 & UCC & Moderately resistant & 14 & UCC-513 & UCC & Resistant \\
\hline 3 & UCC-32 & UCC & Moderately resistant & 15 & UCC-523 & UCC & Resistant \\
\hline 4 & UCC-153 & UCC & Resistant & 16 & UCC-Early & UCC & Resistant \\
\hline 5 & UCC-221 & UCC & Resistant & 17 & Padi-Tuya & SARI & Moderately resistant \\
\hline 6 & UCC-241 & UCC & Moderately resistant & 18 & Apagbaala & SARI & Resistant \\
\hline 7 & UCC-328 & UCC & Resistant & 19 & IT08K-125-107 & IITA & Resistant \\
\hline 8 & UCC-366 & UCC & Resistant & 20 & IT08K-193-14 & IITA & Resistant \\
\hline 9 & UCC-445 & UCC & Moderately resistant & 21 & IT10K-817-3 & IITA & Moderately susceptible \\
\hline 10 & UCC-466 & UCC & Resistant & 22 & IT10K-819-4 & IITA & Moderately resistant \\
\hline 11 & UCC-473 & UCC & Resistant & 23 & IT10K-832-3 & IITA & Resistant \\
\hline 12 & UCC-484 & UCC & Resistant & 24 & IT97K-499-35 & IITA & Resistant \\
\hline
\end{tabular}

c) Assessment of leaf photosynthetic rate in cowpea genotypes

Net photosynthetic rates of cowpea genotypes at six weeks germination were determined with the miniPPM-300 photosynthesis system at mean light intensity of $400 \mu \mathrm{mol}$ photons $\mathrm{m}^{-2} \mathrm{~s}^{-1}$, photosynthetically active radiation (PAR) of 400-700 nm, temperature of $31{ }^{\circ} \mathrm{C}$ and relative humidity of $53 \%$. Rust-infected and uninfected intact leaves in the uppermost layers of five cowpea plants excluding border plants were randomly selected per subplot. Rust-infected leaves showed the presence of pustules with different levels of severities while uninfected leaves showed absence of pustules on both abaxial and adaxial leaf surfaces. Three photosynthetic measurements were taken at $5 \mathrm{~min}$ intervals on each leaflet with an area of $7 \mathrm{~cm}^{2}$. The net photosynthetic rate was calculated according to the model: $(1-(F / F m)) \times$ PAR, where $F$ is fluorescence yield, Fm is maximum fluorescence yield, and PAR is photosynthetically active radiation (Genty et al., 1989; van der Tol et al., 2014).

d) Assessment of rust disease severity in cowpea genotypes

The severity of rust disease on the infected leaves were measured to determine the effect of rust infection on photosynthetic rates of the genotypes. Rust severities were assessed by direct estimation using a diagrammatic scale by Godoy et al. (1997), where $0=0 \%, 1=1-10 \%, 2=11-25 \%, 3=26-50 \%$, $4=51-75 \%$, and $5=76-100 \%$ of the leaf area covered by pustules on the adaxial and abaxial leaf surfaces.

e) Measurement of growth and yield parameters in cowpea genotypes

The relationship between growth and yield parameters and mean $\beta$ value of cowpea genotypes were assessed during the cropping season. The growth parameters were determined by measuring plant height and canopy diameter at six weeks germination. The number of branches per plant was obtained by a numerical count of individual branches emerging from the main stem of each sampled plant.

The yield parameters measured were the number of days to $50 \%$ flowering, number of pods per peduncle, pod length, number of seeds per pod, 100seed weight, and seed yield. The number of days to $50 \%$ flowering for each cowpea genotype was determined by counting the number of days from seed sowing to $50 \%$ flowering of the plants. A numerical count of the number of pods per peduncle was done for each sampled plant at eight weeks germination. The dried cowpea pods on each subplot (excluding border plants) were harvested and air-dried. Fifteen pods were randomly selected from each subplot, and the lengths and number of seeds per pod were determined. All the pods were threshed, and 100 seeds of each cowpea genotype were randomly counted and weighed. The total seed yield of each cowpea genotype $\left(\mathrm{kg} \mathrm{ha}^{-1}\right)$ was estimated.

\section{f) Data analysis}

The relationships between rust disease severities and photosynthetic rates were determined by Bastiaans (1991) model: $P_{x} / P_{o}=(1-x)^{\beta}$, where $P_{x}$ is net photosynthetic rate of a leaf with disease severity $x$, $P_{o}$ is net photosynthetic rate of a healthy leaf, and $\beta$ (Beta) is a ratio between virtual lesion area and visual lesion area. The value of $\beta$ was determined using nonlinear regression in GenStat v16.1.0 (VSN International Ltd, UK). Two-sided $t$-test was used to compare $\beta$ values with 1 , and significant differences in $\beta$ values were determined among cowpea genotypes. 
Analyses of variance (ANOVA) were conducted to test variation in growth and yield components of cowpea genotypes, and significant differences in seed yield were separated with the Tukey test. The relationships between the relative net photosynthetic rates and seed yield of cowpea genotypes were performed by linear regression. Principal component analysis (PCA) biplot of the estimated $\beta$ values, growth and yield traits was constructed to assess relatedness among the variables and distribution of cowpea genotypes under rust infection.

\section{Results}

a) Relationships between rust disease severity and leaf photosynthesis

Rust disease severity differed significantly $(P<0.001)$ with an average of $21.50 \pm 7.33 \%$ among the cowpea genotypes. The highest disease severity $(75.40 \pm 3.97 \%)$ was observed in IT08K-817-3 (Table 2). In contrast, UCC-11 showed the lowest severity of 10.20 $\pm 3.34 \%$. The net photosynthetic rate of healthy leaves and rust-infected leaves did not differ significantly $(P=0.91)$. In healthy leaves, the net photosynthetic rate ranged from $29.53 \mu \mathrm{mol} \mathrm{m} \mathrm{m}^{-2} \mathrm{~s}^{-1}$ (IT08K-193-14) to $98.12 \mu \mathrm{mol} \mathrm{m} \mathrm{m}^{-2} \mathrm{~s}^{-1}$ (Apagbaala). UCC-Early recorded the highest net photosynthetic rate of $78.80 \mu \mathrm{mol} \mathrm{m} \mathrm{m}^{-2} \mathrm{~s}^{-1}$, whereas IT08K-193-14 recorded the lowest net photosynthetic rate of $28.74 \mu \mathrm{mol} \mathrm{m} \mathrm{m}^{-2} \mathrm{~s}^{-1}$ in rust-infected leaves. Eleven cowpea genotypes (IT97K-499-35, IT10K819-4, IT10K-832-3, UCC-221, UCC-241, UCC-366, UCC-473, UCC-490, UCC-513, UCC-523, and UCCEarly) showed higher net photosynthetic rates in rustinfected leaves compared with healthy leaves.

The model by Bastiaans (1991) effectively characterized the effect of rust disease on photosynthesis of the cowpea genotypes (Table 2). The estimated $\beta$ values differed significantly $(P<0.001)$ from 1 with coefficient of determination $\left(\mathrm{r}^{2}\right)$ ranging between 0.88 and 0.98 (average of 0.94). Rust infection considerably reduced relative net photosynthetic rate $(\beta>1)$ than expected in all the cowpea genotypes except IT08K-817-3 ( $\left.\beta=0.93 \pm 0.23, r^{2}=0.95\right)$. The reduction was severest in IT97K-499-35 ( $\beta=9.94 \pm$ $\left.1.74, r^{2}=0.93\right)$. Similar observations were made in UCC-490 ( $\left.\beta=9.53 \pm 1.08, r^{2}=0.97\right)$, UCC-366 $\left(\beta=9.52 \pm 1.56, r^{2}=0.92\right)$, and UCC-473 $(\beta=9.31 \pm$ $\left.1.34, r^{2}=0.96\right)$. High values of $\beta$ ranging from 5.49 to 7.50 (average $r^{2}$ of 0.96 ) were found in six cowpea genotypes (Apagbaala, UCC-11, UCC-24, UCC-241, IT08K-193-14, and IT10K-832-3). Besides, regression analysis of relative net photosynthetic rates and rust severities for the 24 cowpea genotypes gave a significant $\beta$ value of $2.98 \pm 0.98$ (Fig. 1).

Table 2: Effect of rust infection on net photosynthetic rates of cowpea genotypes on-field

\begin{tabular}{|c|c|c|c|c|c|c|}
\hline \multirow{2}{*}{ Genotype } & \multirow{2}{*}{ Severity (\%) } & \multicolumn{2}{|c|}{ Net photosynthetic rate } & \multirow{\beta}{*}{$\begin{array}{c}\text { Standard } \\
\text { error of } \boldsymbol{\beta}\end{array}$} & \multirow{2}{*}{$\mathrm{r}^{2}$} \\
\cline { 3 - 4 } & & Healthy leaves & Rust-infected leaves & & 0.97 \\
\hline UCC-11 & $10.20 \pm 3.34$ & $60.31 \pm 13.86$ & $49.27 \pm 10.32$ & 7.50 & 1.35 & 0.97 \\
\hline UCC-24 & $17.00 \pm 4.65$ & $52.39 \pm 12.94$ & $33.32 \pm 9.34$ & 6.09 & 0.94 & 0.96 \\
\hline UCC-32 & $20.10 \pm 4.09$ & $62.26 \pm 9.84$ & $55.15 \pm 10.52$ & 4.11 & 0.74 & 0.97 \\
\hline UCC-153 & $11.10 \pm 4.83$ & $58.02 \pm 9.81$ & $53.17 \pm 10.59$ & 2.27 & 0.57 & 0.96 \\
\hline UCC-221 & $17.30 \pm 5.71$ & $45.47 \pm 10.42$ & $63.88 \pm 15.18$ & 2.92 & 0.89 & 0.91 \\
\hline UCC-241 & $15.90 \pm 5.75$ & $37.21 \pm 9.52$ & $44.57 \pm 10.36$ & 5.49 & 0.96 & 0.94 \\
\hline UCC-328 & $53.00 \pm 8.83$ & $63.45 \pm 15.71$ & $38.97 \pm 18.41$ & 1.88 & 0.71 & 0.80 \\
\hline UCC-366 & $14.50 \pm 4.82$ & $31.07 \pm 5.62$ & $36.77 \pm 10.74$ & 9.52 & 1.56 & 0.92 \\
\hline UCC-445 & $11.10 \pm 6.37$ & $71.86 \pm 15.83$ & $46.85 \pm 10.78$ & 3.66 & 0.85 & 0.93 \\
\hline UCC-466 & $14.40 \pm 4.80$ & $53.38 \pm 13.18$ & $39.43 \pm 8.93$ & 3.19 & 0.81 & 0.92 \\
\hline UCC-484 & $19.70 \pm 4.48$ & $52.66 \pm 11.17$ & $51.80 \pm 9.58$ & 4.92 & 0.77 & 0.95 \\
\hline UCC-473 & $17.70 \pm 2.75$ & $33.25 \pm 4.11$ & $63.86 \pm 16.56$ & 9.31 & 1.34 & 0.96 \\
\hline UCC-490 & $16.30 \pm 4.08$ & $45.13 \pm 7.90$ & $52.56 \pm 10.93$ & 9.53 & 1.08 & 0.97 \\
\hline UCC-513 & $16.30 \pm 4.02$ & $46.77 \pm 10.09$ & $68.86 \pm 13.10$ & 3.69 & 0.94 & 0.97 \\
\hline UCC-523 & $19.40 \pm 7.28$ & $46.00 \pm 8.96$ & $54.90 \pm 7.54$ & 2.52 & 0.78 & 0.93 \\
\hline UCC-Early & $16.90 \pm 5.34$ & $55.47 \pm 8.71$ & $78.80 \pm 13.26$ & 3.33 & 0.74 & 0.91 \\
\hline Padi-Tuya & $23.40 \pm 5.71$ & $65.54 \pm 10.84$ & $59.69 \pm 9.06$ & 4.48 & 0.71 & 0.97 \\
\hline Apagbaala & $21.70 \pm 5.73$ & $98.12 \pm 20.06$ & $58.68 \pm 10.88$ & 7.37 & 1.28 & 0.95 \\
\hline IT10K-125-107 & $15.00 \pm 4.06$ & $51.38 \pm 6.78$ & $32.52 \pm 5.98$ & 4.15 & 0.49 & 0.98 \\
\hline IT08K-193-14 & $16.40 \pm 5.37$ & $29.53 \pm 7.14$ & $28.74 \pm 7.69$ & 7.19 & 0.87 & 0.97 \\
\hline IT97K-499-35 & $14.20 \pm 4.81$ & $42.36 \pm 8.03$ & $64.95 \pm 18.41$ & 9.94 & 1.74 & 0.93 \\
\hline IT08K-817-3 & $75.40 \pm 3.97$ & $67.43 \pm 9.90$ & $58.56 \pm 14.05$ & 0.93 & 0.23 & 0.95 \\
\hline IT10K-819-4 & $46.00 \pm 6.11$ & $39.95 \pm 7.91$ & $71.29 \pm 13.47$ & 2.49 & 0.97 & 0.88 \\
\hline IT10K-832-3 & $13.10 \pm 3.61$ & $44.26 \pm 10.70$ & $55.37 \pm 6.94$ & 5.85 & 0.99 & 0.97 \\
\hline
\end{tabular}




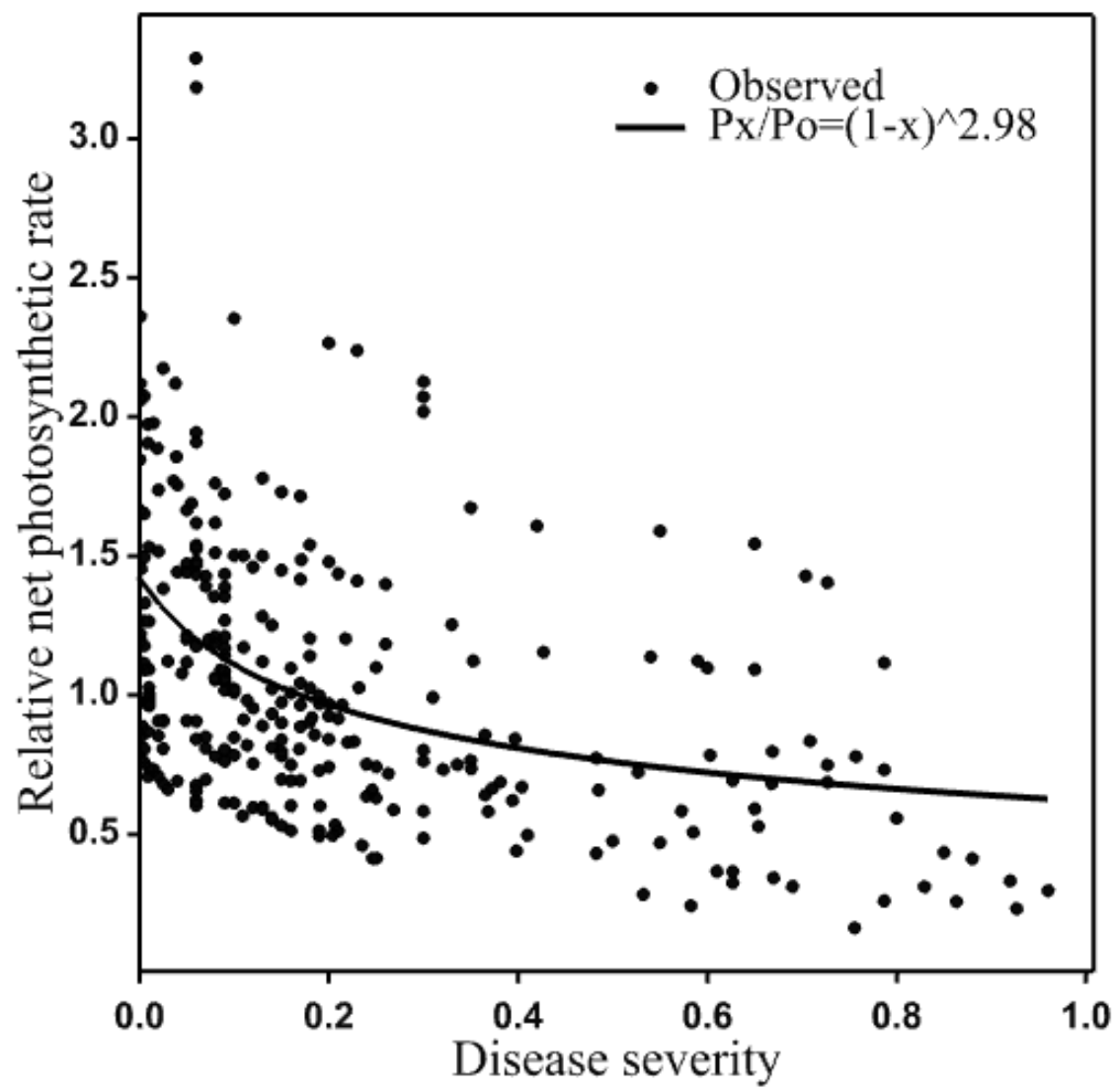

Fig. 1: Relative net photosynthetic rate of cowpea leaves in relation to rust disease severity

b) Effect of rust infection on growth and yield performance of cowpea genotypes under field conditions

Growth and yield parameters significantly differed $(P<0.001)$ among cowpea genotypes. Cowpea genotypes showed significant differences $(P \leq 0.017)$ in plant height $(30.85 \pm 1.42 \mathrm{~cm}$, $P \leq 0.001)$, number of branches $(3.79 \pm 0.15 \mathrm{~cm}$, $\mathrm{P} \leq 0.001)$, canopy diameter $(95.14 \pm 6.35 \mathrm{~cm}$, $P=0.017)$, days to $50 \%$ flowering $(41.12 \pm 0.63 \mathrm{~cm}$, $P \leq 0.001)$, pod length $(16.16 \pm 0.34 \mathrm{~cm}, P \leq 0.001)$, number of seeds per pod $(13.39 \pm 0.23 \mathrm{~cm}$, $P=0.003), 100$-seed weight (17.04 $\pm 0.56 \mathrm{~g}$, $P<0.001)$, and seed yield $\left(850.14 \pm 51.02 \mathrm{~kg} \mathrm{ha}^{-1}\right.$, $P=0.002$ ) (Table 3). However, there was no difference in number of pods per peduncle (2.06 \pm 0.03 , $P=0.566)$ among the cowpeas. UCC-Early recorded the highest plant height $(46.10 \pm 6.12 \mathrm{~cm})$, whereas Apagbaala showed the lowest plant height $(18.64 \pm 1.46 \mathrm{~cm})$. The highest number of branches $(5.25 \pm 0.73)$, canopy diameter $(183.91 \pm 43.30 \mathrm{~cm})$, and pod length $(21.00 \pm 1.70 \mathrm{~cm})$ was found in UCC466, UCC-366, and IT10K-819-4 respectively.

Days to $50 \%$ flowering was relatively low in UCC-490 (36.43 \pm 0.08), UCC-221 (36.50 \pm 0.00), UCC-Early (36.62 \pm 2.19$)$, UCC-32 (37.80 \pm 0.00$)$, and Apagbaala (37.00 \pm 0.00$)$ compared with IT08K-817$3(46.33 \pm 0.33)$ and IT10K-819-4 (46.86 \pm 3.48)
(Table 3). Five cowpea genotypes (UCC-328, UCC-473, UCC-484, UCC-490, and UCC-513) gave the highest mean number of pods per peduncle $(2.33 \pm 0.33)$. The number of seeds per pod (15.00) was highest in UCC11, UCC-Early, and IT97K-499-35. IT10K-819-4 showed the highest 100 -seed weight $(24.50 \pm 1.19 \mathrm{~g})$ followed by Padi-Tuya $(23.50 \pm 0.65 \mathrm{~g})$. Padi-Tuya, however, recorded the highest seed yield $\left(1,389.17 \mathrm{~kg} \mathrm{ha}^{-1}\right)$. UCC-153, UCC-523, and UCC-32 similarly had high seed yield values of $1,330.00 \mathrm{~kg} \mathrm{ha}^{-1}, 1,162.50 \mathrm{~kg} \mathrm{ha}^{-1}$, and $1,155.00 \mathrm{~kg} \mathrm{ha}^{-1}$ respectively, whereas UCC-366, IT08K-193-14, and UCC-Early recorded low seed yield of $490.83 \mathrm{~kg} \mathrm{ha}^{-1}, 504.17 \mathrm{~kg} \mathrm{ha}^{-1}$, and $539.17 \mathrm{~kg} \mathrm{ha}^{-1}$ respectively. 
Table 3: Comparison of growth and yield performance of cowpea genotypes infected with rust fungus on-field

\begin{tabular}{|c|c|c|c|c|c|c|c|c|c|}
\hline Genotype & $\begin{array}{l}\text { Plant Height } \\
(\mathrm{cm})\end{array}$ & $\begin{array}{c}\text { No. of } \\
\text { Branching }\end{array}$ & $\begin{array}{c}\text { Canopy } \\
\text { Diameter }(\mathrm{cm}) \\
\end{array}$ & \begin{tabular}{|c|} 
Days to $50 \%$ \\
Flowering \\
\end{tabular} & \begin{tabular}{|l|}
$\begin{array}{c}\text { No. of Pods/ } \\
\text { peduncle }\end{array}$ \\
\end{tabular} & \begin{tabular}{|c|} 
Pod Length \\
$(\mathrm{cm})$
\end{tabular} & $\begin{array}{c}\text { No. of } \\
\text { Seeds/ pod }\end{array}$ & $\begin{array}{l}\text { 100-Seed } \\
\text { Weight }(\mathrm{g})\end{array}$ & $\begin{array}{c}\text { Seed Yield } \\
\left(\mathrm{kg} \mathrm{ha}^{-1}\right)\end{array}$ \\
\hline UCC-11 & $34.13 \pm 3.32$ & $3.89 \pm 0.59$ & $111.13 \pm 14.83$ & $41.00 \pm 0.00$ & $2.00 \pm 0.00$ & $16.83 \pm 0.78$ & $15.00 \pm 0.58$ & $18.00 \pm 0.41$ & $1005.83^{\text {abc }}$ \\
\hline UCC-24 & $2.11 \pm 3.73$ & $4.22 \pm 0.43$ & $55.12 \pm 5.09$ & $39.80 \pm 0.00$ & $2.00 \pm 0.00$ & $17.00 \pm 0.32$ & $12.67 \pm 0.33$ & $18.67 \pm 0.33$ & $801.25^{\text {abc }}$ \\
\hline UCC-32 & $25.19 \pm 1.56$ & $4.22 \pm 0.47$ & $108.32 \pm 27.31$ & $37.80 \pm 0.00$ & $2.00 \pm 0.00$ & $15.97 \pm 0.57$ & $13.00 \pm 0.00$ & $20.00 \pm 0.58$ & $1155.00^{\mathrm{abc}}$ \\
\hline UCC-153 & $35.81 \pm 2.31$ & $2.67 \pm 0.37$ & $124.94 \pm 36.64$ & $38.30 \pm 0.00$ & $2.33 \pm 0.33$ & $16.63 \pm 1.22$ & $13.67 \pm 1.33$ & $17.00 \pm 0.41$ & $1330.00^{\mathrm{ab}}$ \\
\hline$\overline{U C C}$ & $.90 \pm 2.05$ & $3.78 \pm 0.47$ & $78.50 \pm 7.50$ & $36.50 \pm 0.00$ & $2.00 \pm 0.00$ & $16.23 \pm 0.15$ & $14.67 \pm 0.33$ & $16.50 \pm 0.29$ & $912.50^{\mathrm{abc}}$ \\
\hline UCC & $.42 \pm 2.44$ & $4.44 \pm 0.44$ & $85.10 \pm 12.82$ & .00 & $2.00 \pm 0.00$ & $15.10 \pm 0.58$ & $12.67 \pm 0.88$ & $16.50 \pm 0.87$ & $682.50^{\mathrm{abc}}$ \\
\hline UCC & $.34 \pm 1.97$ & $4.89 \pm 0.39$ & $40.73 \pm 45.39$ & 00 & $2.33 \pm 0.33$ & $15.50 \pm 0.89$ & $12.67 \pm 1.20$ & $16.75 \pm 0.63$ & $846.67^{\text {abc }}$ \\
\hline UCC-3 & $30.47 \pm 2.85$ & $4.56 \pm 0.50$ & 183.9 & 50 & $2.00 \pm 0.00$ & $14.33 \pm 0.03$ & $14.00 \pm 0.58$ & $15.00 \pm 0.41$ & $490.83^{c}$ \\
\hline UCC-445 & $28.11 \pm 3.27$ & $3.67 \pm 0.62$ & $104.90 \pm 23.17$ & $40.80 \pm 0.00$ & $2.00 \pm 0.00$ & $14.57 \pm 0.37$ & $13.00 \pm 0.58$ & $17.75 \pm 0.48$ & $958.33^{\text {abc }}$ \\
\hline UC & $26.75 \pm 3.92$ & $5.25 \pm 0.73$ & $135.36 \pm 19.20$ & .00 & $1.67 \pm 0.33$ & $13.13 \pm 0.09$ & $11.00 \pm 0.58$ & $17.00 \pm 0.41$ & $649.17^{\text {abc }}$ \\
\hline$\overline{\mathrm{UC}}$ & $92 \pm 0.83$ & $4.44 \pm 0.34$ & 8.47 & 06 & $2.33 \pm 0.33$ & $14.90 \pm 0.27$ & $13.00 \pm 0.58$ & $14.25 \pm 0.63$ & $784.17^{\mathrm{abc}}$ \\
\hline & $.46 \pm 2.32$ & $3.00 \pm 0.50$ & .46 & .17 & $2.33 \pm 0.33$ & \begin{tabular}{|l|}
$15.20 \pm 0.87$ \\
\end{tabular} & $11.00 \pm 1.16$ & $14.67 \pm 0.88$ & $728.75^{\mathrm{abc}}$ \\
\hline UCC-490 & $25.01 \pm 2.44$ & $3.11 \pm 0.42$ & $59.34 \pm 4.44$ & $36.43 \pm 0.08$ & $2.33 \pm 0.33$ & $15.17 \pm 0.43$ & $11.67 \pm 0.89$ & $16.25 \pm 1.84$ & $633.33^{\mathrm{abc}}$ \\
\hline UCC-513 & $28.46 \pm 3.56$ & $3.44 \pm 0.48$ & $79.19 \pm 25.19$ & $38.80 \pm 0.00$ & $2.00 \pm 0.00$ & $16.13 \pm 0.92$ & $13.00 \pm 1.00$ & $16.75 \pm 0.25$ & $1031.67^{\mathrm{abc}}$ \\
\hline UCC-523 & $31.24 \pm 4.05$ & $5.11 \pm 0.56$ & $105.04 \pm 14.60$ & $40.25 \pm 0.25$ & $2.00 \pm 0.00$ & $16.60 \pm 0.67$ & $14.00 \pm 0.00$ & $15.25 \pm 0.48$ & $1162.50^{\mathrm{abc}}$ \\
\hline UCC-Early & $46.10 \pm 6.12$ & $2.78 \pm 0.36$ & 74.72 & 36.62 & $2.00 \pm 0.00$ & $18.47 \pm 1.13$ & $15.00 \pm 0.58$ & $13.25 \pm 0.48$ & $539.17^{\mathrm{bc}}$ \\
\hline $\mathrm{Pa}$ & $36.20 \pm 3.39$ & $3.33 \pm 0.17$ & 113.4 & 44.2 & \pm 0.00 & $18.77 \pm 0.39$ & $14.33 \pm 0.33$ & $23.50 \pm 0.65$ & $1389.17^{\mathrm{a}}$ \\
\hline Apagh & $18.64 \pm 1.46$ & $4.33 \pm 0.33$ & 6.35 & 37.00 & $2.00 \pm 0.00$ & $14.60 \pm 0.21$ & $13.00 \pm 0.00$ & $14.00 \pm 1.08$ & $829.17^{\mathrm{abc}}$ \\
\hline IT10K-125-107 & $29.04 \pm 1.86$ & $3.44 \pm 0.24$ & $=32.74$ & 1.48 & $2.00 \pm 0.00$ & $17.40 \pm 0.67$ & $13.33 \pm 0.33$ & $19.25 \pm 0.25$ & $1065.83^{\mathrm{abc}}$ \\
\hline IT08K-193-14 & $25.31 \pm 2.02$ & $2.89 \pm 0.42$ & $109.56 \pm 31.30$ & $45.31 \pm 2.03$ & $2.00 \pm 0.00$ & $15.90 \pm 0.55$ & $13.33 \pm 0.67$ & $18.00 \pm 1.00$ & $504.17^{\mathrm{bC}}$ \\
\hline IT97K-499-35 & $29.09 \pm 1.70$ & $3.56 \pm 0.69$ & $94.46 \pm 23.13$ & $40.80 \pm 0.00$ & $2.00 \pm 0.00$ & $17.47 \pm 0.89$ & $15.00 \pm 1.16$ & $15.75 \pm 0.63$ & $632.50^{a b c}$ \\
\hline & $43.16 \pm 3.30$ & $3.67 \pm 0.24$ & 62.83 & & $2.00 \pm 0.00$ & $15.90 \pm 0.61$ & $14.00 \pm 0.00$ & $16.50 \pm 0.50$ & $895.00^{\mathrm{abc}}$ \\
\hline & $45.06 \pm 3.92$ & $3.56 \pm 0.41$ & 70.78 & 48 & $2.00 \pm 0.00$ & $21.00 \pm 1.70$ & $13.67 \pm 0.89$ & $24.50 \pm 1.19$ & $790.83^{\mathrm{abc}}$ \\
\hline IT10K-832-3 & $38.51 \pm 2.56$ & $2.78 \pm 0.62$ & $61.97 \pm 6.45$ & $44.02 \pm 2.32$ & $2.00 \pm 0.00$ & $14.93 \pm 0.64$ & $14.67 \pm 0.33$ & $13.75 \pm 0.63$ & $585.00^{\mathrm{abc}}$ \\
\hline Mean & 30.85 & 3.79 & 95.14 & 41.12 & 2.06 & 16.16 & 13.39 & 17.04 & 850.14 \\
\hline S.e. of mean \pm & 1.42 & 0.15 & 6.35 & 0.63 & 0.03 & 0.34 & 0.23 & 0.56 & 51.02 \\
\hline$P$ value & $<0.001$ & $<0.001$ & 0.017 & $<0.001$ & 0.566 & $<0.001$ & 0.003 & $<0.001$ & 0.002 \\
\hline
\end{tabular}

c) Relationship between relative net photosynthetic rate and seed yield of cowpea genotypes

The linear regression analysis revealed variations in the relationship between the relative net photosynthetic rate and seed yield of cowpea genotypes as shown by the coefficient of linear estimation $(\gamma)$ (Table 4). A unit increase in the relative net photosynthetic rate decreased seed yield $(-0.790 \pm$ $1.260<\gamma<-0.006 \pm 0.139)$ in 11 cowpea genotypes. The highest effect was observed in IT08K-193-14 followed by UCC-24 (-0.726 \pm 0.428$)$. In contrast, an increase in the relative net photosynthetic rate increased seed yield in 13 cowpeas. The linear coefficient estimates were high in UCC-490 $(\gamma=0.554 \pm 0.121)$,
UCC-Early $(\gamma=0.533 \pm 0.713)$, and UCC-241 $(\gamma=0.386 \pm 0.193)$. Padi-Tuya $(\gamma=0.002 \pm 0.086)$ and Apagbaala $(\gamma=-0.006 \pm 0.139)$ recorded the lowest $\gamma$ estimates for reduction and increase in seed yield among the cowpea genotypes, respectively. The relative net photosynthetic rates in UCC-221 $(\gamma=-0.077 \pm$ $0.001)$ and UCC-473 ( $\gamma=-0.172 \pm 0.012)$ accounted for the most variation $\left(r^{2}=0.99\right)$ in seed yield with significant differences ( $P=0.011$ and 0.045). However, the relative net photosynthetic rates of seven cowpea genotypes (UCC-153, UCC-Early, Apagbaala, PadiTuya, IT10K-125-107, IT08K-193-14, and IT10K-819-4) were inconclusive $\left(r^{2}=0.00\right)$ (Table 4$)$.

Table 4: Linear regression analysis of relative net photosynthetic rate and seed yield of cowpea genotypes

\begin{tabular}{|c|c|c|c|}
\hline Genotype & Y-intercept & $\gamma$ & $\mathrm{r}^{2}$ \\
\hline UCC-11 & $0.302 \pm 0.089$ & $0.059 \pm 0.047$ & 0.24 \\
\hline UCC-24 & $1.445 \pm 0.701$ & $-0.726 \pm 0.428$ & 0.48 \\
\hline UCC-32 & $0.612 \pm 0.069$ & $-0.119 \pm 0.047$ & 0.71 \\
\hline UCC-153 & $0.821 \pm 0.333$ & $-0.232 \pm 0.257$ & 0.00 \\
\hline UCC-221 & $0.428 \pm 0.001$ & $-0.077 \pm 0.001^{*}$ & 0.99 \\
\hline UCC-241 & $-0.087 \pm 0.187$ & $0.386 \pm 0.193$ & 0.60 \\
\hline UCC-328 & $-0.026 \pm 0.045$ & $0.222 \pm 0.025$ & 0.97 \\
\hline UCC-366 & $0.374 \pm 0.153$ & $-0.175 \pm 0.144$ & 0.19 \\
\hline UCC-445 & $0.323 \pm 0.017$ & $0.032 \pm 0.007$ & 0.91 \\
\hline UCC-466 & $0.316 \pm 0.013$ & $-0.042 \pm 0.009$ & 0.91 \\
\hline UCC-484 & $0.081 \pm 0.129$ & $0.232 \pm 0.123$ & 0.56 \\
\hline UCC-473 & $0.379 \pm 0.015$ & $-0.172 \pm 0.012^{*}$ & 0.99 \\
\hline UCC-490 & $-0.264 \pm 0.116$ & $0.554 \pm 0.121$ & 0.91 \\
\hline UCC-513 & $0.334 \pm 0.009$ & $0.114 \pm 0.014$ & 0.97 \\
\hline UCC-523 & $0.365 \pm 0.031$ & $0.117 \pm 0.036$ & 0.83 \\
\hline
\end{tabular}




\begin{tabular}{|c|c|c|c|}
\hline UCC-Early & $-0.160 \pm 0.512$ & $0.533 \pm 0.713$ & 0.00 \\
\hline Padi-Tuya & $0.553 \pm 0.109$ & $0.002 \pm 0.086$ & 0.00 \\
\hline Apagbaala & $0.341 \pm 0.219$ & $-0.006 \pm 0.139$ & 0.00 \\
\hline IT10K-125-107 & $0.487 \pm 0.382$ & $-0.037 \pm 0.235$ & 0.00 \\
\hline IT08K-193-14 & $0.990 \pm 1.250$ & $-0.790 \pm 1.260$ & 0.00 \\
\hline IT97K-499-35 & $0.559 \pm 0.059$ & $-0.357 \pm 0.065$ & 0.94 \\
\hline IT08K-817-3 & $0.269 \pm 0.041$ & $0.044 \pm 0.015$ & 0.79 \\
\hline IT10K-819-4 & $0.133 \pm 0.253$ & $0.282 \pm 0.365$ & 0.00 \\
\hline IT10K-832-3 & $0.123 \pm 0.098$ & $0.140 \pm 0.115$ & 0.19 \\
\hline
\end{tabular}

d) Principal component analysis (PCA) biplot of estimated $\beta$ values, and growth and yield traits

Principal component analysis (PCA) biplot demarked cowpea genotypes with variations in traits explained by principal components 1 (PC1) and 2 (PC2) (Fig. 2). PC1 accounted for $29.21 \%$ of the variation observed in the cowpea genotypes. Pod length (PL) and plant height $(\mathrm{PH})$ correlated most to this variation with values of 0.510 and 0.469 , respectively (Data not shown). PC2 similarly explained $18.49 \%$ of the variation. This observation was mainly spanned by the number of branches (NB) and canopy diameter (CD) with values of -0.537 and -0.463 , respectively (Data not shown). The $\beta$ estimate contributed high values to the variations in PC1 $(-0.279)$ and PC2 (0.341) and showed a significant $(P=0.016)$ negative linear relationship to seed yield. UCC-513 revealed average performance in each trait as well as $\beta$ value with close relatedness to UCC-24 and UCC-221. Padi-Tuya and IT10K-819-4 genotypes showed similar performance but were most dissimilar to UCC-466, UCC-490, UCC-Early, and Apagbaala.

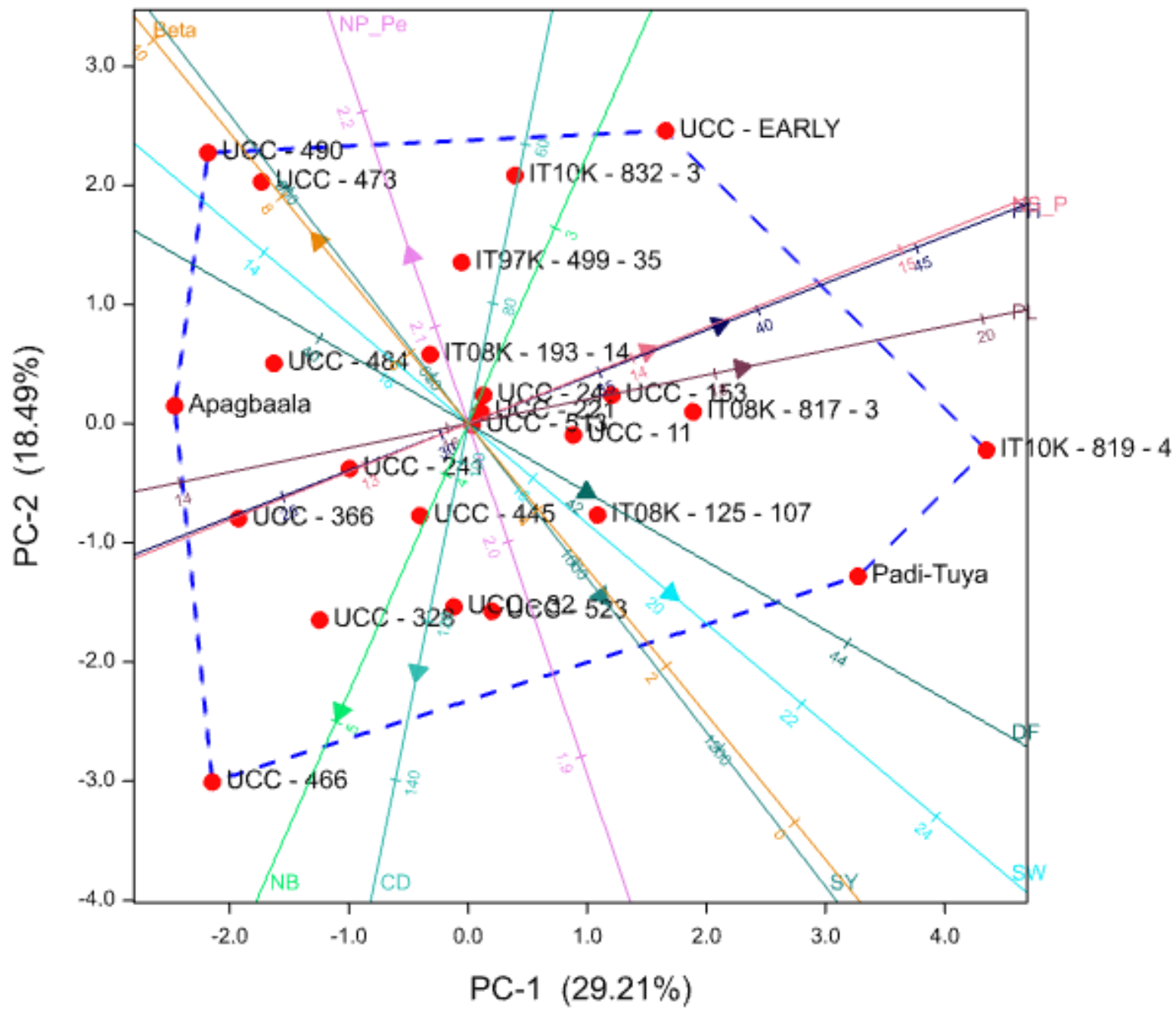

Fig. 2: Principal component analysis (PCA) biplot of estimated $\beta$ values, growth and yield parameters of cowpea genotypes to open field rust infection 


\section{Discussion}

The extent of rust disease damage to cowpea depends on the level of resistance of the cowpea genotype to the pathogen in the face of favorable environmental conditions for the pathogen's developpment. Cowpea genotypes that were studied in this work showed varied responses to rust severity. The variations observed suggest that the cowpea genotypes have different levels of resistance and recovery rates to cowpea rust infection. This finding conforms to the study by Mensah et al. (2019), who reported that different cowpea genotypes respond differently to rust infection. Similar observations in rust disease severities of cowpeas have been reported (Edema and Adipala, 1995; Uma et al., 2015).

In the present study, cowpea genotypes 56 showed varied responses in net photosynthetic rates of rust-infected and healthy leaves. The differences in net photosynthetic rates of the cowpea genotypes may be due to differences in anatomical, biochemical and physiological characteristics of the cowpea genotypes because photosynthetic efficiency of cowpea remain the same after development of rust pustules regardless of the stage of disease development, incubation temperature, phenological stage of the host, and cultivar-type (Bassanezi et al., 2001; Rivas et al., 2016; Santos et al., 2009; Wentworth et al., 2006). Despite these variations, there was a lack of significant difference in the average net photosynthetic rates recorded for rust-infected and healthy cowpea leaves. Plants are considered to accumulate dry matter in healthy areas of diseased leaves proportional to the amount of photosynthetically active radiation (PAR) that the healthy tissue intercepts (Robert et al., 2004). A ring of enhanced photosynthesis has been detected surrounding an area with decreased photosynthesis at the infection sites of Albugo candida and Botrytis cinerea in Arabidopsis and tomato leaves, respectively (Berger et al., 2007). Besides, rust infection may be latent within healthy leaves of cowpea genotypes. Livne (1964) observed no appreciable difference in photosynthetic rate between a heavily rust-infected and healthy bean leaves using radioactivity before a visible symptom of rust infection. Currently, it is not clear if this photosynthetic response in disease infected plants is due to the defense strategy of the plants (Berger et al., 2007).

Bastiaans' model, however, revealed that rust infection generally reduced the net photosynthetic rate ( $\beta=2.98)$ of the asymptomatic leaf area of cowpea genotypes. The $\beta$ value was similar to that reported for leaf rust of bean $(\beta=2.17)$ and wheat $(\beta=2.20)$ cultivars (Bassanezi et al., 2001; Robert et al., 2004). Whereas the reduction in photosynthesis to rust infection was higher $(\beta>1)$ in 23 cowpea genotypes, the photosynthetic efficiency in rust diseased leaf areas in IT08K-817-3 was functionally active $(\beta<1)$. The differential responses of the cowpea genotypes to the pathogen may account for the differences in estimated $\beta$ values for the genotypes. Erickson et al. (2004) similarly observed larger disparity in $\beta$ values (1.49 and 6.94) of two clones of hybrid poplar plants in response to the leaf spot pathogen, Marssonina brunnea. Pathogenic infection in plants generally leads to a reduction in photosynthetic efficiency (Kocal et al., 2008) as observed in this work. Similar observations were made by Bauer et al. (2000) and Zhao et al. (2011) on the infection of needle rust fungus, Chrysomyxa rhododendri in Norway spruce and orange rust fungus, Puccinia kuehnii in sugarcane plants. In contrast, Robert et al. (2005) showed that wheat leaf rust fungus (Puccinia triticina) did not affect the photosynthetic rate of symptomless parts of rust-infected wheat leaves.

The significant variations in plant height, number of branching, canopy diameter, days to 50\% flowering, pod length, number of seeds per pod, 100seed weight, and seed yield indicate existence of sufficient genetic variability in the cowpea germplasm and potential for improvement in cowpea production. Several studies have similarly observed significant differences in growth and yield components of cowpea genotypes, as observed in this study (Futuless and Bake, 2010; Kwaga, 2014; Manggoel and Uguru, 2011; Nwofia et al., 2014; Pethe et al., 2017). An earlier study has contrarily reported a significant difference in the number of pods per peduncle (Aliyu and Makinde, 2016).

These variations in growth and yield parameters may be due to differences in environmental conditions and inherent genetic characteristics of the cowpea genotypes (Badr et al., 2014; Basaran et al., 2011; Mafakheri et al., 2017; Sarath and Reshma, 2017). Xu et al. (2017) established genomic regions, cellular components, and gene regulatory basis as factors responsible for variations in pod length of cowpea cultivars. Several studies have shown that the magnitude of genotypic correlation coefficients was higher than their corresponding phenotypic and environmental correlation coefficients on growth and yield components of cowpea genotypes (Nwosu et al., 2013; Shweta and Singh, 2018; Umar et al., 2010).

All the cowpea genotypes were early flowering ( $<45$ days) except IT08K-817-3 and IT10K-819-4, which were late flowering ( $>45$ days). Earlier studies in cowpea have reported early flowering and late flowering genotypes (Manggoel and Uguru, 2011; Singh, 1993). The seed yields of the cowpea genotypes were low compared with the seed yields reported by Tettey et al. (2018) during the major cropping season in the coastal savannah agro-ecological zone. This variation may be due to the high mean temperature of $28.5^{\circ} \mathrm{C}$ and rainfall of $545.5 \mathrm{~mm}$ observed in the present study compared with low mean temperature of $27.3{ }^{\circ} \mathrm{C}$ and rainfall of 
$171.0 \mathrm{~mm}$ reported during the study (Tettey, 2017), which influenced rust development and disease severity. A study on rust infection in cowpea genotypes in the coastal savannah agro-ecology reported higher rust disease incidence and severity in the minor season compared with the major season and concluded that temperature and rainfall are positively associated with cowpea rust disease incidence, severity, and area under disease progress curve (Mensah et al., 2019). Robert et al. (2004) indicated a significant reduction in seed yields of rust-infected wheat cultivars compared with healthy (control) wheat cultivars under field conditions.

Even though the effect of rust disease on photosynthesis was higher $(\beta>1)$ than the visual lesion in Padi-Tuya compared with IT08K-817-3 $(\beta<1)$, the genotype had the highest seed yield. Similar variations in the seed yield were recorded among the cowpea genotypes amidst the estimated $\beta$ values. These differences may be due to genetic, morphological, and phenotypic variations among the cowpea genotypes. Moreover, stem photosynthesis may be important for biomass accumulation in rust-infected plants (Robert et al., 2004). Studies have identified quantitative trait loci underlying these physiological changes in photosynthetic efficiency, and growth and yield traits of cowpea genotypes to rust infection (Lo et al., 2018; Wu et al., 2018a; Wu et al., 2018b).

Rust infection in cowpea leads to significant losses in biomass yields due to a reduction in relative net photosynthetic rates (Deshpand et al., 2010; Staples, 2001; Voegele and Mendgen, 2003). Quantification of responses of cowpea genotypes to rust infection is, therefore, important to predict potential yield losses in the genotypes. Linear regression analysis of relative net photosynthetic rates and seed yields of cowpea genotypes showed that an increase in the relative net photosynthetic rates of UCC-473 and UCC221 genotypes reduced seed yields by $7.7 \%$ and $17.2 \%$, respectively. However, the modeling tool could not establish a relationship between variations in relative net photosynthetic rates and variations in seed yields of the remaining cowpea genotypes. This suggests that a relationship between relative net photosynthetic rate and seed yield in cowpea genotypes to rust infection may not be a direct effect but an interaction of factors. This lack of direct correlation has been noted by earlier studies and attributed to the single leaf measurement of photosynthetic efficiency at only one stage in the host's development other than photosynthetic efficiency of the whole crop over time (Evans, 1993; Long et al., 2006).

The distribution of the cowpea genotypes, as observed in the PCA biplot indicates a wide phenotypic variability, which was accounted for largely by UCC-466, UCC-490, UCC-Early, Apagbaala, and IT10K-819-4. UCC-513, UCC-221, and UCC-24 were the most stable cowpea genotypes with regards to the effect of rust infection on net photosynthetic rates ( $\beta$ value), and growth and yield parameters. The $\beta$ value correlated to seed yield with a significant difference and revealed that an increase in $\beta$ value decreases seed yield in cowpea genotypes. This observation, coupled with the regression analysis, confirms that variation in seed yield is stimulated by photosynthetic efficiency and an interaction variable in the face of rust infection. This interaction variable to photosynthetic efficiency has been noted by earlier studies as the available light energy, efficiency of light interception, and harvest index which collectively describe the physiological and structural properties of the host (Long et al., 2006; Simkin et al., 2019; Zhu et al., 2010).

\section{Conclusions}

Cowpea rust infection altered net photosynthetic rates, and growth and yield parameters in cowpea genotypes. The pathogen generally reduced net photosynthetic efficiency beyond the visible lesion areas on host leaves. The PCA biplot analysis using estimated $\beta$ values revealed a significant negative relationship between rust disease severity and seed yields among the genotypes. Rust-resistant cowpea genotypes should, therefore, be used to control cowpea rust fungus. The $\beta$ value could be used as an effective index to select for potential high-yielding genotypes, which could reduce the time frame and cost of breeding. UCC-24, UCC-241, and UCC-513 showed higher stability to rust infection and can be recommended to farmers for cultivation within the coastal savannah agro-ecological zone of Ghana. The high phenotypic variability associated with UCC-466, UCC-490, UCC-Early, Padi-Tuya, Apagbaala, and IT10K-819-4 can be explored in cowpea breeding programs to improve the crop.

\section{ACKNOWLEDGEMENTS}

The authors thank the Food and Agriculture Organization (FAO) and the International Treaty on Plant Genetic Resources for Food and Agriculture (ITPGRFA) for their financial support for the study.

\section{References Références Referencias}

1. Abate, T., Alene, A. D., Bergvinson, D., Shiferaw, B., Silim, S., Orr, A., Asfaw, S., 2012. Tropical grain legumes in Africa and south Asia: knowledge and opportunities. International Crops Research Institute for the Semi-Arid Tropics, Nairobi, Kenya

2. Adigun, J., Osipitan, A. O., Lagoke, S. T., Adeyemi, R. O., Afolami, S.O., 2014. Growth and yield performance of cowpea (Vigna unguiculata (L.) Walp) as influenced by row-spacing and period of weed interference in south-west Nigeria. J. Agric. Sci. 6, 188-198.

3. Afutu, E., Mohammed, K. E., Odong, T. L., Biruma, M., Rubaihayo, P. R., 2016. Evaluation of Ugandan 
cowpea germplasm for yield and resistance to scab disease. Am. J. Exp. Agric. 12, 1-18.

4. Agrios, G. N., 2004. Plant pathology. Elsevier Academic Press, Burlington.

5. Agyeman, K., Berchie, J. N., Bonsu, I., Nartey, T. E., Fordjour, J. K., 2014. Growth and yield performance of improved cowpea (Vigna unguiculata L.) varieties in Ghana. Agric. Sci. 2, 44-52.

6. Aliyu, O. M., Makinde, B. O., 2016. Phenotypic analysis of seed yield and yield components in cowpea (Vigna unguiculata L., Walp). Plant Breed. Biotechnol. 4, 252-261.

7. Ambavaram, M.M.R., Basu, S., Krishnan, A., Ramegowda, V., Batlang, U., Rahman, L., Baisakh, N., Pereira, A., 2014. Coordinated regulation of photosynthesis in rice increases yield and tolerance to environmental stress. Nat. Commun. 5, 1-14.

8. Badr, A., Ahmed, H.I.S., Hamouda, M., Halawa, M., Elhiti, M. A., 2014. Variation in growth, yield and molecular genetic diversity of M2 plants of cowpea following exposure to gamma radiation. Life Sci. J. 11, 10-19.

9. Basaran, U., Ayan, I., Acar, Z., Mut, H., Asci, O. O., 2011. Seed yield and agronomic parameters of cowpea (Vigna unguiculata L.) genotypes grown in the Black Sea region of Turkey. Afr. J. Biotechnol. 10, 13461-13464.

10. Bassanezi, R. B., Amorima, L., Bergamin Filhoa, A., Haub, B., Bergerc, R. D., 2001. Accounting for photosynthetic efficiency of bean leaves with rust, angular leaf spot and anthracnose to assess cropdamage. Plant Pathol. 50, 443-452.

11. Bastiaans, L., 1991. Ratio between virtual and visual lesion size as a measure to describe reduction in leaf photosynthesis of rice ue to Leaf Blast. Phytopathol. 81, 611-615.

12. Bate, G. C., Canvin, D. T., 1971. A gas-exchange system for measuring the productivity of plant populations in controlled environments. Can. J. Bot. 49, 601-608.

13. Bauer, H., Plattner, K., Volgger, W., 2000. Photosynthesis in Norway spruce seedlings infected by the needle rust Chrysomyxa rhododendri. Tree Physiol. 20, 211-216.

14. Berger, S., Sinha, A. K., Roitsch, T., 2007. Plant physiology meets phytopathology: plant primary metabolism and plant-pathogen interactions. J. Exp. Bot. 58, 4019-4026.

15. Brito, M., Fernández-Rodríguez, T., Garrido, M., Mejías, A., Romano, M., Marys, E., 2012. First report of Cowpea mild mottle carlavirus on yardlong bean (Vigna unguiculata subsp. sesquipedalis) in Venezuela. Viruses 4, 3804-3811.

16. Cate, T. M., Perkins, T. D., 2003. Chlorophyll content monitoring in sugar maple (Acer saccharum). Tree Physiol. 23, 1077-1079.
17. Chapin III, F. S., Eviner, V. T., 2003. Biogeochemistry of terrestrial net primary production, In: Turekian, K. K., Holland, H. D. (Eds.), Treatise on geochemistry. Elsevier Ltd, pp. 215-247.

18. Chapman, S. C., Barreto, H. J., 1997. Using a chlorophyll meter to estimate specific leaf nitrogen of tropical maize during vegetative growth. Agron. J. 89, 557-562.

19. De Abreu Costa, L., Ottoni, M.H.F., dos Santos, M. G., Meireles, A. B., de Almeida, V. G., Pereira, W.d.F., de Avelar-Freitas, B. A., Brito-Melo, G.E.A., 2017. Dimethyl Sulfoxide (DMSO) decreases cell proliferation and TNF- $\alpha$, IFN- $\gamma$, and IL-2 cytokines production in cultures of peripheral blood lymphocytes. Molecules 22, 1789.

20. Deshpand, K. S., Patil, B. R., Salimath, P. M., Nidagundi, J. M., Karthigeyan, S., 2010. Evaluation of native and collected Germplasm for earliness Seed traits and resistance to rust, CMV and leaf spot in Cowpea [Vigna unguiculata (L.) Walp]. Electron. J. Plant Breed. 1, 384-392.

21. Dugje, I. Y., Omoigui, L. O., Ekeleme, F., Kamara, A. Y., Ajeigbe, H., 2009. Farmers' guide to cowpea production in West Africa. IITA, Ibadan, Nigeria.

22. Dutton, R. G., Jiao, J., Tsujita, M. J., Grodzinski, B., 1988. Whole plant $\mathrm{CO}_{2}$ exchange measurements for nondestructive estimation of growth. Plant Physiol. 86, 355-358.

23. EARS, 2009. miniPPM-300: User Manual. EARS, Wageningen, The Netherlands.

24. Edema, R., Adipala, E., 1995. Relationships between brown and false rusts and cowpea yields Crop Prot. 14, 395-398.

25. Ehleringer, J. R., Cerling, T. E., 2002. The earth system: biological and ecological dimensions of global environmental change: C3 and C4 photosynthesis, In: Mooney, H., Canadell, J. (Eds.), Encyclopedia of Global Environmental Change. Wiley \& Sons, Chichester, UK, pp. 186-190.

26. Elmore, C. D., 1980. The paradox of no correlation between leaf photosynthetic rates and crop yields, In: Hesketh, J. D., Jones, J. W. (Eds.), Predicting Photosynthesis for Ecosystem Models. CRC Press, Boca Raton, FL, pp. 155-168.

27. Erickson, J. E., Stanosz, G. R., Kruger, E. L., 2004. Photosynthetic consequences of Marssonina leaf spot differ between two poplar hybrids. New Phytol. 161, 577-583.

28. Etemadian, Y., Shabanpour, B., Ghaemi, V., Kordjazi, M., 2017. Compare the Chlorophyll Amount in Three Brown Algae Species of the Persian Gulf by using Three Solvents and Applying Two Formulas. Int. J. Biochem. Biophys. Mol. Biol. 2, 77-79.

29. Evans, J. R., 2013. Improving photosynthesis. Plant Physiol. 162, 1780-1793. 
30. Evans, T. L., 1993. Crop evolution, adaptation and yield. Cambridge University Press, Cambridge.

31. Fernandez-Jaramillo, A. A., Duarte-Galvan, C., Contreras-Medina, L. M., Torres-Pacheco, I., Romero-Troncoso, R.D.J., Guevara-Gonzalez, R. G., Millan-Almaraz, J. R., 2012. Instrumentation in developing chlorophyll fluorescence biosensing: A review. Sens. 12, 11853-11869.

32. Futuless, K. N., Bake, I. D., 2010. Evaluation of yield and yield attributes of some cowpea (Vigna unguiculata $(\mathrm{L})$. Walp) varieties in northern Guinea Savanna. J. Am. Sci. 6, 508-511.

33. Genty, B., Briantais, J.-M., Baker, N. R., 1989. The relationship between the quantum yield of photosynthetic electron transport and quenching of chlorophyll fluorescence. Biochim. Biophys. Acta. Bioenerg. 990, 87-92.

34. Godoy, C. V., Carneiro, S.M.T.P.G., lamauti, M. T., Pria, M. D., Amorim, L., Berger, R. D., Filho, A. B., 1997. Diagrammatic scales for bean diseases: development and validation. J. Plant Dis. Prot. 104, 336-345.

35. Hailemichael, G., Catalina, A., Gonzalez, M.R., Martin, P., 2016. Relationships between water status, leaf chlorophyll content and photosynthetic performance in Tempranillo vineyards. S. Afr. J. Enol. Vitic. 37, 149-156.

36. Ho, L. C., 1976. Variation in the carbon/dry matter ratio in plant material. Ann. Bot. 40, 163-165.

37. Honnur, R. B., Yadahalli, K. B., Jahagirdar, S., 2016. Identification of susceptible stage for rust in cowpea. Biochem. Cell. Arch. 16, 141-143.

38. Jiang, C., Johkan, M., Hohjo, M., Tsukagoshi, S., Ebihara, M., Nakaminami, A., Maruo, T., 2017. Photosynthesis, plant growth, and fruit production of single-truss tomato improves with supplemental lighting provided from underneath or within the inner canopy. Sci. Hortic. 222, 221-229.

39. Kadam, D. B., Salvi, S., Chandanwale, A., 2018. Methanol Poisoning. J. Assoc. Physicians India 66, 47-50.

40. Kamble, P. N., Giri, S. P., Mane, R. S., Tiwana, A., 2015. Estimation of chlorophyll content in young and adult leaves of some selected plants. Univ. J. Environ. Res. Technol. 6, 306-310.

41. Kassman, A. H., Van Velthuizen, H. T., Fischer, G. W., Shah, M. M., 1991. Agro-ecological land resources assessment for agricultural development planning. A case study of Kenya: resources data base and land productivity. Main report. World Soil Res. Rep.

42. Kocal, N., Sonnewald, U., Sonnewald, S., 2008. Cell wall-bound invertase limits sucrose export and is involved in symptom development and inhibition of photosynthesis during compatible interaction between tomato and Xanthomonas campestris pv vesicatoria. Plant Physiol. 148, 1523-1536.
43. Kumar, D., Narain, P., 2005. Production technology for cowpea. ACIRP on Arid Legumes, Jodhpur, India.

44. Kwaga, Y. M., 2014. Direct and Indirect Contribution of Yield Attributes to the Grain Yield of Cowpea [Vigna unguiculata (L.) Walp], grown in Northern Guinea Savanna, Nigeria. Res. J. Pharm. Biol. Chem. Sci. 5, 1671-1679.

45. Leonard, K. J., Szabo, L. J., 2005. Stem rust of small grains and grasses caused by Puccinia graminis. Mol. Plant Pathol. 6, 99-111.

46. Ling, Q., Huang, W., Jarvis, P., 2011. Use of a SPAD-502 meter to measure leaf chlorophyll concentration in Arabidopsis thaliana. Photosynth. Res. 107, 209-214.

47. Livne, A., 1964. Photosynthesis in healthy and rustaffected plants. Plant Physiol. 39, 614-621.

48. Lo, S., Muñoz-Amatriaín, M., Boukar, O., Herniter, I., Cisse, N., Guo, Y.-N., Roberts, P. A., Xu, S., Fatokun, C., Close, T. J., 2018. Identification of QTL controlling domestication-related traits in cowpea (Vigna unguiculata L. Walp). Sci. Rep. 8, 1-9.

49. Lobato, A.K.S., Gonçalves-Vidigal, M. C., Vidigal Filho, P. S., Andrade, C.A.B., Kvitschal, M. V., Bonato, C. M., 2010. Relationships between leaf pigments and photosynthesis in common bean plants infected by anthracnose. N. Z. J. Crop Hortic. Sci. 38, 29-37.

50. Long, G., Meek, M. E., Lewis, M., 2001. N, $\mathrm{N}$-Dimethylformamide. WHO, Geneva.

51. Long, S. P., Marshall-Colon, A., Zhu, X.-G., 2015. Meeting the global food demand of the future by engineering crop photosynthesis and yield potential. Cell 161, 56-66.

52. Long, S. P., Zhu, X. G., Naidu, S. L., Ort, D. R., 2006. Can improvement in photosynthesis increase crop yields? Plant Cell Environ. 29, 315-330.

53. Mafakheri, K., Bihamta, M. R., Abbasi, A. R., 2017. Assessment of genetic diversity in cowpea (Vigna unguiculata L.) germplasm using morphological and molecular characterisation. Cogent Food Agric. 3, 1-20.

54. Makeen, K., Babu, G. S., Lavanya, G. R., Grard, A., 2007. Studies of chlorophyll content by different methods in black gram (Vigna mungo L.). Int. J. Agric. Res. 2, 651-654.

55. Manggoel, W., Uguru, M. I., 2011. Comparative study on the phenology and yield components of two photoperiodic groups of cowpea (Vigna unguiculata (L.) Walp.) in two cropping seasons. Afr. J. Agric. Res. 6, 5232-5241.

56. Mensah, T. A., Tagoe, S.M.A., Asare, A. T., Agyirifo, D.S., 2019. Screening of Cowpea (Vigna unguiculata L. Walp) Genotypes for Rust (Uromyces phaseoli var. vignae) Resistance in Ghana. Plant 6, 67-74. 
57. Newcombe, G., 2004. Rust diseases, In: Burley, J., Evans, J., Youngquist, J. (Eds.), Encyclopedia of Forest Sciences. Elsevier Science Publishing Co Inc, San Diego, USA, pp. 785-792.

58. Nwofia, G. E., Nwanebu, M. C., Mbah, E. U., 2014. Yield and Yield Component Responses of Some Cowpea Varieties to Population Density Structures under Rainfed Conditions in Lowland Tropics of Southeast Nigeria. World J. Agric. Sci. 10, 68-75.

59. Nwosu, D. J., Olatunbosun, B. D., Adetiloye, I. S., 2013. Genetic variability, heritability and genetic advance in cowpea genotypes in two agroecological environments. Greener J. Biol. Sci. 3, 202-207.

60. Pethe, U. B., Dodiya, N. S., Bhave, S. G., Dadheech, A., Meghawal, D. R., 2017. Heterosis for yield and yield related traits in cowpea (Vigna unguiculata $\mathrm{L}$. Walp). J. Pharmacogn. Phytochem. 6, 1247-1249.

61. Rivas, R., Falcão, H. M., Ribeiro, R. V., Machado, E. C., Pimentel, C., Santos, M. G., 2016. Drought tolerance in cowpea species is driven by less sensitivity of leaf gas exchange to water deficit and rapid recovery of photosynthesis after rehydration. S. Afr. J. Bot. 103, 101-107

62. Robert, C., Bancal, M. O., Ney, B., Lannou, C., 2005. Wheat leaf photosynthesis loss due to leaf rust, with respect to lesion development and leaf nitrogen status. New Phytol. 165, 227-241.

63. Robert, C., Bancal, M. O., Nicolas, P., Lannou, C., Ney, B., 2004. Analysis and modelling of effects of leaf rust and Septoria tritici blotch on wheat growth. J. Exp. Bot. 55, 1079-1094

64. Rusike, J., van den Brand, G. J., Boahen, S., Dashiell, K., Katengwa, S., Ongoma, J., Mongane, D. M., Kasongo, G., Jamagani, Z. B., Aidoo, R., 2013. Value chain analyses of grain legumes in N2Africa: Kenya, Rwanda, eastern DRC, Ghana, Nigeria, Mozambique, Malawi and Zimbabwe. N2Africa.

65. Santos, M. G., Ribeiro, R. V., Machado, E. C., Pimentel, C., 2009. Photosynthetic parameters and leaf water potential of five common bean genotypes under mild water deficit. Biol. Plant. 53, 229-236.

66. Sarath, P. S., Reshma, T., 2017. Genetic variability studies in cowpea (Vigna unguiculata L. Walp). Int. J. Agric. 7, 129-132.

67. Sharma, P. P., Baranda, B., Haritwal, S., Sharma, M., 2017. Character Association for Seed Yield and Its Components in Cowpea [Vigna unguiculata (L.)Walp]. Int. J. Curr. Microbiol. App. Sci. 6, 967975.

68. Sheikh, A. Q., Pandit, A. K., Ganai, B. A., 2017. Seasonal variation in chlorophyll content of some selected plant species of Yousmarg grassland ecosystem. Asian J. Plant Sci. Res. 7, 33-36.

69. Shweta, A. S., Singh, V., 2018. Estimates of Genetic Variability, Heritability and Genetic Advance For
Yield and Yield Component Traits in Indian Cowpea [Vigna unguiculata (L.) Walp.] Int. J. Pure App. Biosci. 6, 1142-1147.

70. Silva, W. C., de Moura, J. G., de Oliveira, A. B., Ferreira, L. E., da Silva, T. M., 2017. Growth and gas exchange in cowpea plants under different managements and saline conditions. Rev. Ciênc. Agron. 48, 756-764.

71. Simkin, A. J., López-Calcagno, P. E., Raines, C. A., 2019. Feeding the world: improving photosynthetic efficiency for sustainable crop production. J. Exp. Bot. 70, 1119-1140.

72. Sims, D. A., Gamon, J. A., 2002. Relationships between leaf pigment content and spectral reflectance across a wide range of species, leaf structures and developmental stages. Remote Sens. Environ. 81, 337-354.

73. Singh, B. B., 1993. Cowpea Breeding: Archival Report (1988-1992) of Grain Legume Improvement Program. IITA, Ibadan, Nigeria.

74. Singh, M., 2011. Pathological and physiological effects of drain water on some cereal and vegetable crops. V. B. S. Purvanchal University, Jaunpur.

75. Staples, R. C., 2001. Nutrients for a rust fungus: the role of haustoria. Trends Plant Sci. 6, 496-498.

76. Steele, M., Gitelson, A. A., Rundquist, D., 2008. Nondestructive estimation of leaf chlorophyll content in grapes. Am. J. Enol. Vitic. 59, 299-305.

77. Stiegler, J., Bell, G., Maness, N., Smith, M., 2005. Spectral detection of pigment concentrations in creeping bentgrass golf greens. Int. Turf. Soc. Res. J. 10, 818-825

78. Sumanta, N., Haque, C. I., Nishika, J., Suprakash, R., 2014. Spectrophotometric analysis of chlorophylls and carotenoids from commonly grown fern species by using various extracting solvents. Res. J. Chem. Sci. 4, 63-69.

79. Tettey, C. K., 2017. Characterisation And Determination Of Virus Resistance Among Cowpea [Vigna Unguiculata (L.) Walp.] Genotypes. University of Ghana, Legon.

80. Tettey, C. K., Asare-Bediako, E., Asare, A. T., Amoatey, H., 2018. Phenotypic screening of cowpea (Vigna unguiculata (L.) Walp) genotypes for resistance to cowpea viral diseases. Afr. J. Food Agric. Nutr. Dev. 18, 13502-13524.

81. Uma, M. S., Hegde, N., Hittalmani, S., 2016. Identification of SSR marker associated with rust resistance in cowpea (Vigna unguiculata L.) using bulk segregant analysis. Legume Res. 39, 39-42.

82. Uma, M. S., Hegde, N., Umesh, H. O., Somashekhar, Y. M., Patil, P. V., 2015. Morphological variability in Uromyces phaseolis var. vignae causing cowpea rust in South India. Karnataka J. Agric. Sci. 28, 96-98.

83. Umar, M. L., Sanusi, M. G., Lawan, F. L., 2010. Relationships between some Quantitative 
Characters in Selected Cowpea Germplasm [(Vigna unguiculata L.(Walp)]. Not. Sci. Biol. 2, 125-128.

84. van der Tol, C., Berry, J. A., Campbell, P.K.E., Rascher, U., 2014. Models of fluorescence and photosynthesis for interpreting measurements of solar-induced chlorophyll fluorescence. J. Geophys. Res: Biogeosci. 119, 2312-2327.

85. Voegele, R. T., Mendgen, K., 2003. Rust haustoria: nutrient uptake and beyond. New Phytol. 159, 93-100.

86. Wentworth, M., Murchie, E. H., Gray, J. E., Villegas, D., Pastenes, C., Pinto, M., Horton, P., 2006. Differential adaptation of two varieties of common bean to abiotic stress: II. Acclimation of photosynthesis. J. Exp. Bot. 57, 699-709.

87. Wu, X., Li, G., Wang, B., Hu, Y., Wu, X., Wang, Y., Lu, Z., Xu, P., 2018a. Fine mapping Ruv2, a new rust resistance gene in cowpea (Vigna unguiculata), to a 193-kb region enriched with NBS-type genes. Theor. Appl. Genet. 131, 2709-2718.

88. Wu, X., Wang, B., Wu, X., Lu, Z., Li, G., Xu, P., 2018b. SNP marker-based genetic mapping of rust resistance gene in the vegetable cowpea landrace ZN016. Legume Res. 41, 222-225.

89. Xu, P., Wu, X., Muñoz-Amatriaín, M., Wang, B., Wu, X., Hu, Y., Huynh, B. L., Close, T. J., Roberts, P. A., Zhou, W., 2017. Genomic regions, cellular components and gene regulatory basis underlying pod length variations in cowpea (V. unguiculata L. Walp). Plant Biotechnol. J. 15, 547-557.

90. Zhao, D., Glynn, N. C., Glaz, B., Comstock, J. C., Sood, S., 2011. Orange rust effects on leaf photosynthesis and related characters of sugarcane. Plant Dis. 95, 640-647.

91. Zhu, X. G., Long, S. P., Ort, D. R., 2010. Improving photosynthetic efficiency for greater yield. Annu. Rev. Plant Biol. 61, 235-261. 